\title{
Synthesis, Spectral Characterization, and Biochemical Evaluation of Antidiabetic Properties of a New Zinc-Diosmin Complex Studied in High Fat Diet Fed-Low Dose Streptozotocin Induced Experimental Type 2 Diabetes in Rats
}

\author{
Veerasamy Gopalakrishnan, ${ }^{1}$ Subramanian Iyyam Pillai, ${ }^{2}$ \\ and Sorimuthu Pillai Subramanian ${ }^{1}$ \\ ${ }^{1}$ Department of Biochemistry, University of Madras, Guindy Campus, Chennai 600 025, India \\ ${ }^{2} P G$ and Research Department of Chemistry, Pachaiyappa's College, Chennai 600 030, India \\ Correspondence should be addressed to Sorimuthu Pillai Subramanian; subbus2020@yahoo.co.in
}

Received 9 September 2015; Accepted 15 November 2015

Academic Editor: Saad Tayyab

Copyright (c) 2015 Veerasamy Gopalakrishnan et al. This is an open access article distributed under the Creative Commons Attribution License, which permits unrestricted use, distribution, and reproduction in any medium, provided the original work is properly cited.

\begin{abstract}
In view of the established antidiabetic properties of zinc, the present study was aimed at evaluating the hypoglycemic properties of a new zinc-diosmin complex in high fat diet fed-low dose streptozotocin induced experimental type 2 diabetes in rats. Zincdiosmin complex was synthesized and characterized by various spectral studies. The complexation between zinc ions and diosmin was further evidenced by $\mathrm{pH}$-potentiometric titrations and Job's plot. Diabetic rats were orally treated with zinc-diosmin complex at a concentration of $20 \mathrm{mg} / \mathrm{kg}$ b.w./rat/day for 30 days. At the end of the experimental period, the rats were subjected to oral glucose tolerance test. In addition, HOMA-IR and various biochemical parameters related to glucose homeostasis were analyzed. Treatment with zinc-diosmin complex significantly improved the glucose homeostasis in diabetic rats. Treatment with zinc-diosmin complex significantly improved insulin sensitivity, at least in part, through enhancing protein metabolism and alteration in the levels of muscle and liver glycogen. The assay of clinical marker enzymes revealed the nontoxic nature of the complex. Determination of renal tissue markers such as blood urea and serum creatinine indicates the renoprotective nature of the complex. These findings suggest that zinc-diosmin complex is nontoxic and has complimentary potential to develop as an antihyperglycemic agent for the treatment of diabetes mellitus.
\end{abstract}

\section{Introduction}

Type 2 diabetes mellitus (T2DM) is a heterogeneous disorder characterized by a progressive decline in insulin sensitivity followed by pancreatic $\beta$-cell dysfunction [1]. The interplay between insulin resistance and $\beta$-cell dysfunction remains elusive [2]. The prevalence of type 2 diabetes has been increasing alarmingly due to sedentary life style, obesity, and lack of exercise. Globally, around 382 million people had diabetes in 2013, with the prediction that this number could be doubled by 2035 [3]. This is a minimum number because, for each diagnosed case, there will be one undiagnosed case in first world and eight in the third world countries [4]. Several hypotheses have been proposed to describe the pathogenesis of type $2 \mathrm{DM}$; however the persistence of microvascular and premature macrovascular complications as the main cause of morbidity and mortality in people with diabetes is a constant reminder that our therapeutic and management strategies are inadequate for most patients [5].

Most of the currently used oral antihyperglycemic drugs such as sulphonylureas, $\alpha$-glycosidase inhibitors, biguanides, and thiazolidinediones for the treatment of type 2 diabetes are often associated with adverse side effects or diminution in response after prolonged use [6]. Hence, the search for novel 
therapeutic agents without having long-term side effects and eliciting better antidiabetic activity at low concentration is necessitated. Many metallic elements play a crucial role in living systems. Some metal ions mimic or sensitize the action of insulin in rodent models as well as in vitro [7-9]. The intentional introduction of a metal ion into the biological system will be for either therapeutic or diagnostic purpose. The use of metal complexes as therapeutic drugs has become highly important over the last couple of decades resulting in a variety of exciting and valuable metallopharmaceutical drugs [10], having a wide range of structural-pharmacological activity relationships, and biochemical aspects of metals binding to cellular targets have lined a new possibility for scientific investigation in metal coordination. Before the discovery of insulin and its clinical use to treat diabetes mellitus, oral administration of sodium vanadate was reported for the treatment of DM in humans [11].

Besides vanadium, zinc also possesses significant insulin mimetic and insulin sensitizing effects [12, 13]. In 1980, Coulston and Dandona reported that zinc ${ }^{2+}$ ions stimulate in vitro rat adipocyte lipogenesis, which was similar to the action of insulin [14]. Zinc is an essential trace element which is distributed in the entire body ( 2 to $4 \mathrm{~g}$ ), and a wide spectrum of proteins and transcription factors contain this metal ion. Zinc is necessary for the stability and function of more than 300 enzymes $[15,16]$. It is well known that $Z n$ plays an important role in the synthesis, storage, and secretion of insulin [17]. Chronic hyperglycemia causes increased urinary loss of zinc and decreased zinc levels in the body [18]. The decreased zinc level adversely affects the ability of the $\beta$-cells in the synthesis and storage of insulin $[19,20]$.

Zinc ions are expected to develop as a clinically useful metallopharmaceutical, like platinum-containing cisplatin and gold-containing auranofin as anticancer and antiarthritic drugs, respectively [21, 22]. However, designing of new zinc complexes requires special attention in terms of stability and structural properties under physiological conditions. Most of the zinc complexes so far investigated for their antidiabetic potential were inadequately absorbed in their inorganic form and required high doses that have been allied with undesirable side effects. In order to circumvent the toxicity and increase gastrointestinal tract absorption of zinc, several complexes have been formulated using ecologically derived nonnutrient plant secondary metabolites as organic ligands and studied for their antidiabetic properties [23-27].

Flavonoids are a diverse group of polyphenolic phytochemicals that are produced as secondary metabolites by various plants to protect them from environmental stress and injury [28]. A large number of flavonoids are known for their wide range of pharmacological effects on human health especially in quenching oxidative stress and preventing secondary complications [29]. Amongst flavonoids, flavones are known to chelate the metal ions with great affinity owing to the presence of $\alpha$-hydroxycarbonyl group and their ability to quench the free radicals [30].

Diosmin (diosmetin-7-O-rutinoside) is one such naturally occurring bioflavone found profusely in the pericarp of citrus plants such as Meyer lemons and Buddha's finger fruits [31]. It was originally isolated from Scrophularia nodosa in 1925 [32] and later it was readily obtained by the dehydrogenation of hesperidin [33]. Diosmin is nontoxic [34] and reported to exhibit a wide range of pharmacological properties including antioxidant [35], antiproliferative [36], anti-inflammatory [37], and antidiabetic effects [38]. Having these beneficial as well as pharmacological aspects in view, in the present study, we have designed and synthesized a new zinc complex using diosmin as an organic ligand and evaluated its antidiabetic properties in high fat diet fed-low dose STZ induced experimental type 2 diabetes in rats.

\section{Materials and Methods}

2.1. Chemicals. Zinc sulphate $\left[\mathrm{ZnSO}_{4} \cdot 7 \mathrm{H}_{2} \mathrm{O}\right]$, diosmin $\left(\mathrm{C}_{28} \mathrm{H}_{32} \mathrm{O}_{15}\right)$, and streptozotocin (STZ) were procured from the Sigma-Aldrich, St. Louis, USA. Ultra-sensitive ELISA kit for rat insulin assay was purchased from Crystal Chem Inc. Life Technologies, India. All the other chemicals and reagents used were of analytical grade.

2.2. Analytical Instruments. The IR spectral studies for both free diosmin and its metal complex were performed in solid state as pressed $\mathrm{KBr}$ pellets using a Perkin-Elmer FTIR spectrophotometer $\left(400-4000 \mathrm{~cm}^{1}\right)$. Jeol Gc-mate mass spectrometer was used to obtain the mass spectrum of the complex. The ${ }^{1} \mathrm{H}$ NMR and ${ }^{13} \mathrm{C}$ NMR of diosmin as well as its complex were obtained at $300 \mathrm{MHz}$ and $500 \mathrm{MHz}$, respectively, using a Bruker AM-500 instrument. The spectral analysis data were recorded without any modification for instrumental characteristics.

2.3. Zinc-Diosmin Complex Synthesis. Molar ratio method was followed in the synthesis of zinc-diosmin complex as previously reported for the synthesis of various zinc complexes with slight modifications [39-42]. Briefly, a DMSO solution $(10 \mathrm{~mL})$ containing zinc sulphate heptahydrate $(0.287 \mathrm{~g}$, $1 \mathrm{mM}$ ) was gradually added to a hot solution of DMSO $(15 \mathrm{~mL})$ containing diosmin $(1.217 \mathrm{~g}, 2 \mathrm{mM})$. The resulting solution was dried in a pressurized rotary evaporator and the complex obtained was washed with diethyl ether and kept under vacuum over anhydrous calcium chloride.

2.4. pH-Potentiometric Titrations. The formation constant of the newly synthesized zinc-diosmin complex was determined by conducting potentiometric titrations using a ELICO Li $120 \mathrm{pH}$ meter fitted with a glass and calomel electrode. The calomel electrode was initially calibrated as a hydrogen concentration probe by titrating known amounts of standardized $\mathrm{HCl}$ against standardized $\mathrm{NaOH}$. A minimum of two independent titrations were carried out at $25^{\circ} \mathrm{C} \pm 10^{\circ} \mathrm{C}$ for probe calibration. The protonation and stability constants were calculated from the $\mathrm{pH}$ data by using program Origin 8.5 lab [43]. For all titrations, the total sample volume was fixed as $20 \mathrm{~mL}$ and the ligand concentration was $1-10 \mathrm{mM}$. Six titrations were carried out for free diosmin alone and fifteen titrations defined the zinc complex equilibria at the $\mathrm{pH}$ range of $2-10$ [44]. 
2.5. Experimental Animals. Male Albino rats of Wistar weighing around 160 to $180 \mathrm{~g}$ were procured from the Tamilnadu Veterinary and Animal Sciences University, Chennai, and were housed under standard husbandry conditions (12 \pm $1 \mathrm{~h}$ light and dark cycle, relative humidity 55\% $\pm 10 \%)$. The animals were fed with balanced diet (Hindustan Lever Ltd., Bangalore, India) and water ad libitum. The rat pellet diet is composed of $55 \%$ nitrogen-free extract, $21 \%$ protein, $5 \%$ fat, and $4 \%$ fiber $(\mathrm{w} / \mathrm{w})$ with sufficient levels of vitamin and mineral. The experimental design was strictly conducted according to the ethical norms approved by the Ministry of Social Justices and Empowerment, Government of India and Institutional Animal Ethics Committee Guidelines (Approval number 02.01.2012), for the examination of experimental pain in conscious animals.

2.6. Acute Toxicity and Dosage Fixation Studies. Acute toxicity studies were performed as per OECD guidelines for testing of chemicals in normal rats. Graded doses $(10,20,25$, and $30 \mathrm{mg} / \mathrm{kg}$ b.w./rat) of zinc-diosmin complex dissolved in $5 \%$ DMSO were orally administered to rats. The changes in food consumption, fluid intake, psychomotor activities, and body weight gain and changes in skin, fur, eyes, salivation, diarrhea, and lethargy in rats were continuously monitored for a period of 30 days. Macroscopic examinations were also performed on vital organs. Oral administration of graded doses of zinc-diosmin complex (10, 20, and $30 \mathrm{mg} / \mathrm{kg}$ b.w./rat/day) for 30 days to determine the dose-dependent hypoglycemic effect in HFD-low dose STZ induced diabetic rats by monitoring the fasting blood glucose levels periodically to fix the effective dose of the zinc-diosmin complex for treatment.

2.7. Experimental Design. The rats were allocated into two dietary regimens by feeding either normal pellet diet (NPD) or high fat diet (HFD) for 2 weeks of dietary manipulation. HFD contains powdered NPD, $365 \mathrm{~g} / \mathrm{kg}$, lard, $310 \mathrm{~g} / \mathrm{kg}$, casein, $250 \mathrm{~g} / \mathrm{kg}$, cholesterol, $10 \mathrm{~g} / \mathrm{kg}$, vitamin and mineral mix, $60 \mathrm{~g} / \mathrm{kg}$, DL-methionine, $3 \mathrm{~g} / \mathrm{kg}$, yeast powder, $1 \mathrm{~g} / \mathrm{kg}$, and $\mathrm{NaCl}, 1 \mathrm{~g} / \mathrm{kg}$. After 2 weeks of HFD supplementation, Group II, Group III, and Group IV rats were injected with a single dose of STZ (35 mg/kg b.w./rat); control rats (Group I) fed with NPD were injected intraperitoneally with the same volume freshly prepared cold citrate buffer $(\mathrm{pH} 4.5,0.1 \mathrm{~mol} / \mathrm{L})$ only [45]. After one week of STZ injection, rats having fasting blood glucose levels $\geq 300 \mathrm{mg} / \mathrm{dL}$ were considered as diabetic rats and chosen for further studies. The animals were divided into four groups, each comprising six rats as follows:

Group I: normal control rats.

Group II: HFD-STZ (i.p. 35 mg/kg b.w.) induced diabetic rats.

Group III: HFD-STZ induced diabetic rats treated with zinc-diosmin complex (20 mg/kg b.w./rat/day) for 30 days.

Group IV: HFD-STZ induced diabetic rats treated with metformin (200 mg/kg b.w./rat/day) for 30 days.
2.8. Oral Glucose Tolerance Test (OGTT). On the day prior to sacrifice, oral glucose tolerance test (OGTT) was performed in all the groups of rats. Blood samples were collected from the lateral tail vein of rats deprived of food overnight. Successive blood sample was taken at 0, 30, 60, 90, and 120 minutes following the oral administration of $2 \mathrm{mg} / \mathrm{kg} \mathrm{b} . \mathrm{w}$. of glucose solution [46].

2.9. Homeostasis Model Assessment of Insulin Resistance. As the insulin abnormality cannot be accurately detected by a single determination of insulin or glucose levels, the insulin resistance was evaluated by homeostasis model assessment of insulin resistance (HOMA-IR) as follows [47]:

HOMA-IR

$$
=\frac{\text { Fasting insulin level } \times \text { Fasting blood glucose }}{405} .
$$

2.10. Biochemical Parameters. At the end of the experimental period, overnight fasted rats were anaesthetized, using ketamine $(80 \mathrm{mg} / \mathrm{kg}$ b.w./rat, i.p.) and sacrificed by cervical decapitation. Blood samples were collected with and without anticoagulant for separation of plasma and serum, respectively. For the estimation of glycogen [48], liver and muscle tissues were excised out, washed with ice-cold saline, and stored at $-70^{\circ} \mathrm{C}$ and used. The basic biochemical parameters such as fasting blood glucose [49], glycosylated hemoglobin [50], plasma protein [51], blood urea [52], and serum creatinine [53] levels were estimated. Urine strips were used to detect the presence of glucose in urine. The levels of plasma insulin and C-peptide were assayed by ELISA using a rat insulin assay kit (Linco Research, St. Charles, MO, USA). The activities of clinical marker enzymes such as aspartate transaminase (AST) [54], alanine transaminase (ALT) [54], and alkaline phosphatase (ALP) [55] in serum were assayed. The activities of glycogen synthase [56] and glycogen phosphorylase [57] in liver tissues were also assayed.

2.11. Statistical Analysis. The results were expressed as mean $\pm \mathrm{SD}$ of six rats per group and the statistical significance was evaluated by "one-way analysis of variance" (ANOVA) using the SPSS (version 16) program followed by least significance test. A value of $P<0.001, P<0.01$, and $P<0.05$ was considered to indicate statistical significance.

\section{Results}

The zinc-diosmin complex $\left(\mathrm{C}_{56} \mathrm{H}_{62} \mathrm{O}_{30} \mathrm{Zn}\right)$ was synthesized by molar ratio method and obtained as a pale orange coloured powder after vacuum evaporation and the yield was about $76 \%$. The schematic representation of complex synthesis is shown in Scheme 1.

The IR spectral data of free diosmin is shown in Figure S1 [IR $\left.\left(\mathrm{KBr}, v \mathrm{~cm}^{-1}\right) 3435[-\mathrm{OH}], 1676(\mathrm{C}=\mathrm{O})\right]$ (see Supplementary Material available online at http://dx.doi.org/10 $.1155 / 2015 / 350829)$. The IR spectrum of the zinc-diosmin complex is represented in Figure 1 [ IR $\left(\mathrm{KBr}, \nu \mathrm{cm}^{-1}\right) 1653(\mathrm{C}-$ $\mathrm{O}-\mathrm{M}), 502(\mathrm{M}-\mathrm{O})]$. Figure 2 represents the EI mass spectrum 

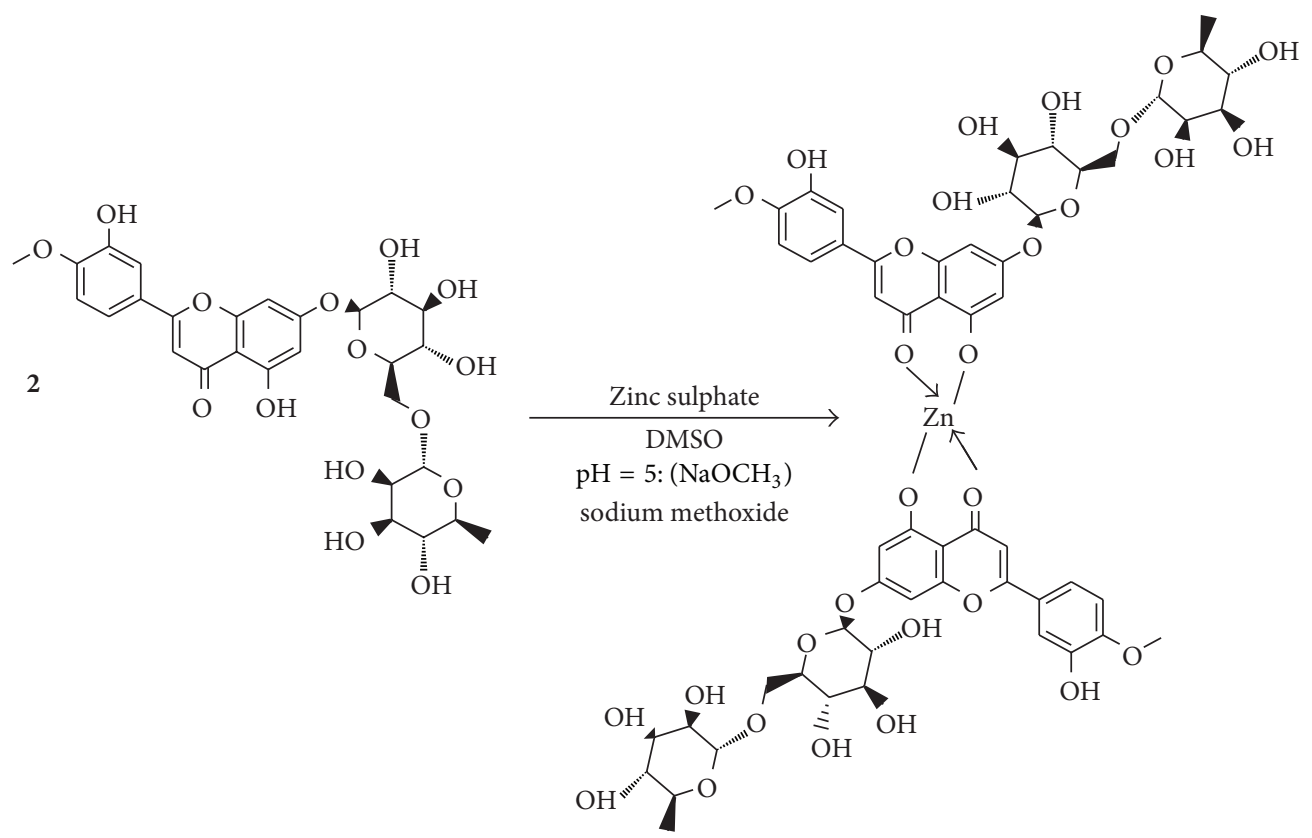

Scheme 1: Structure of zinc-diosmin complex.

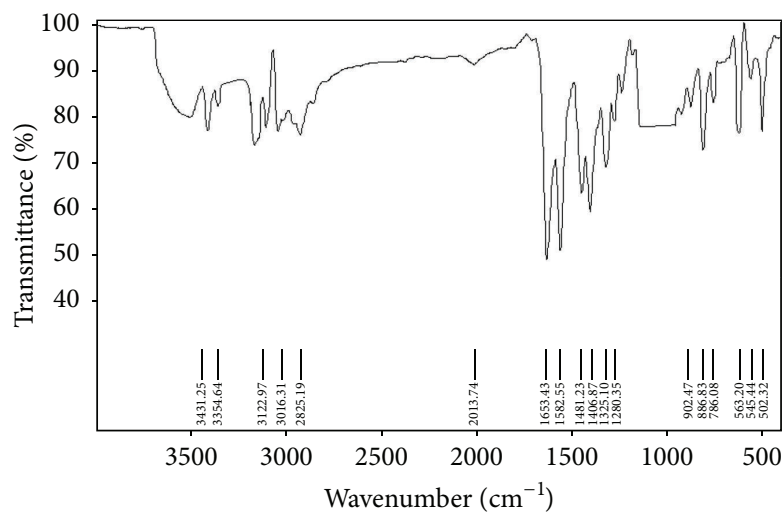

FIgURE 1: IR spectrum of zinc-diosmin complex.

of complex $(\mathrm{m} / \mathrm{z}): 1280$. Elemental analysis calculated for $\mathrm{C}_{56} \mathrm{H}_{62} \mathrm{O}_{30} \mathrm{Zn}(1280) \mathrm{C}, 52.53 ; \mathrm{H}, 4.88$. Found $\mathrm{C}, 52.47 ; \mathrm{H}$, 4.80. The ${ }^{1} \mathrm{H} N M R$ and ${ }^{13} \mathrm{C}$ NMR analysis of the zinc-diosmin complex are depicted in Figures 3 and 4, respectively. The ${ }^{1} \mathrm{H}-\mathrm{NMR}$ analysis of free diosmin (Figure S2) shows the resonances with coupling constants as follows (DMSO- $\mathrm{d}_{6}$, $300 \mathrm{~Hz}) \delta \mathrm{H}: 6.97(\mathrm{~d}, 1 \mathrm{H}, J=6.38 \mathrm{~Hz}), 6.68(\mathrm{~d}, 1 \mathrm{H}, J=$ $6.82 \mathrm{~Hz}), 6.44(\mathrm{~s}, 1 \mathrm{H}), 6.24(\mathrm{~d}, 1 \mathrm{H}, J=6.9 \mathrm{~Hz}), 5.84(\mathrm{~s}, 2 \mathrm{H})$, $5.68(\mathrm{~d}, 1 \mathrm{H}, J=6.74 \mathrm{~Hz}), 5.11(\mathrm{~d}, 1 \mathrm{H}, J=6.6 \mathrm{~Hz}), 4.83(\mathrm{~s}, 2 \mathrm{H})$, $4.22(\mathrm{~d}, 1 \mathrm{H}, J=6.9 \mathrm{~Hz}), 3.97(\mathrm{~d}, 1 \mathrm{H}, J=7.2 \mathrm{~Hz}), 3.84(\mathrm{t}, 1 \mathrm{H}$, $J=8.8 \mathrm{~Hz}), 3.79(\mathrm{~s}, 3 \mathrm{H}), 3.72(\mathrm{~d}, 1 \mathrm{H}, J=6.3 \mathrm{~Hz}), 3.54(\mathrm{q}$, $2 \mathrm{H}), 3.31(\mathrm{t}, 2 \mathrm{H}, \mathrm{J}=10.2 \mathrm{~Hz}), 3.19(\mathrm{~m}, 2 \mathrm{H}), 1.98(\mathrm{~s}, 6 \mathrm{H}), 1.46$ $(\mathrm{s}, 3 \mathrm{H})$. The ${ }^{13} \mathrm{C}-\mathrm{NMR}$ analysis of free diosmin (Figure S3) shows the carbon resonances at $\left(\mathrm{DMSO}_{\mathrm{6}}, 500 \mathrm{~Hz}\right): 183.2$, $164.8,163.5,162.6,158.7,151.1,145.7,124.5,119.7,114.1,112.8$, 104.7, 104.4, 102.0, 97.4, 96.3, 77.0, 76.2, 74.2, 73.3, 73.1, 73.0, $71.4,70.3,65.4,56.9,18$.

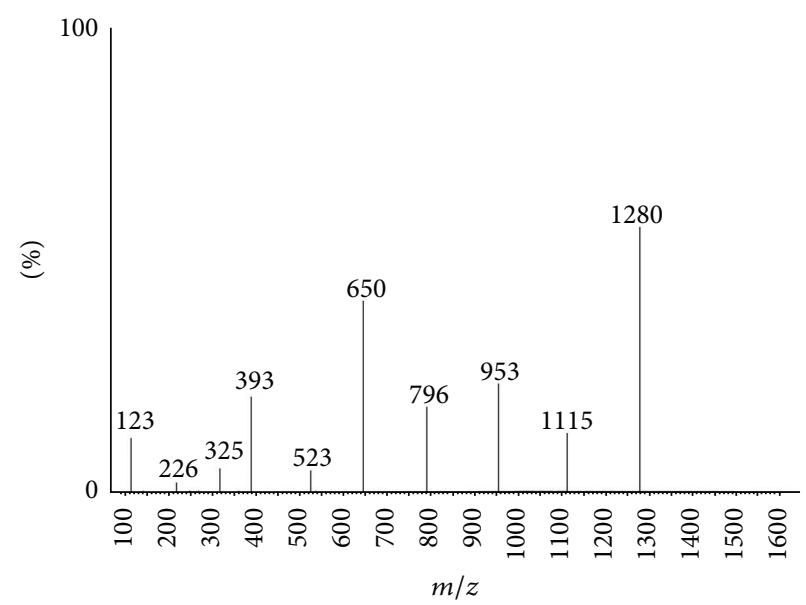

Figure 2: Mass spectrum of zinc-diosmin complex.

Further, $\mathrm{pH}$-potentiometric titrations were carried out (Figure 5) to understand the complex formation between zinc ion and diosmin molecules, by reported methods for other zinc complexes [58-60]. The stability constants of zincdiosmin complex were listed below as (2), (3), (4), and (5). Potentiometric titrations of synthesized complex were reliable with the pattern of equilibria described earlier for synthesized metal complexes [61]. The analysis of the results was consistent with the subsequent equilibria:

$$
\begin{gathered}
\mathrm{H}^{+}+\mathrm{L}^{-} \rightleftharpoons \mathrm{HL} \quad \log K \alpha=9.25 \\
\mathrm{Zn}^{2+}+\mathrm{L}^{-} \rightleftharpoons \mathrm{Zn}(\mathrm{L})^{+} \quad \log K_{1}=9.86
\end{gathered}
$$




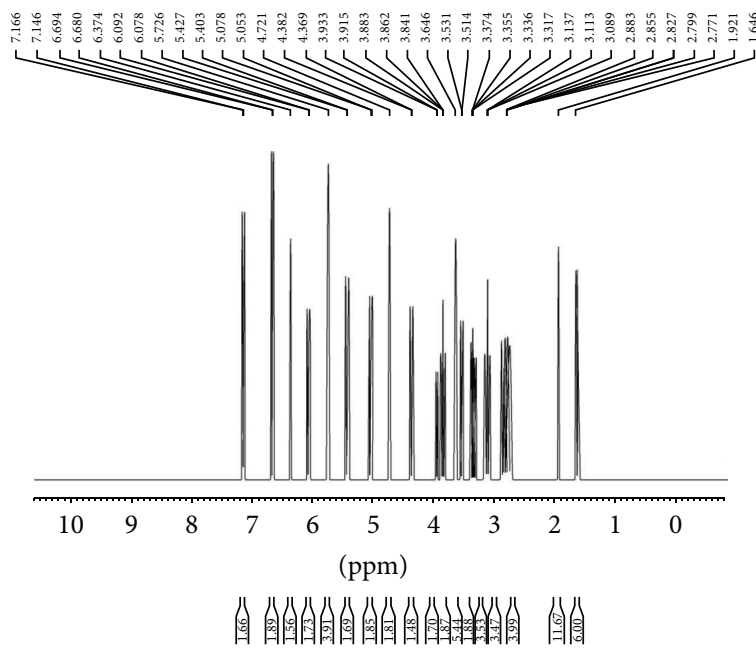

Figure $3:{ }^{1} \mathrm{H}$ NMR of zinc-diosmin complex.

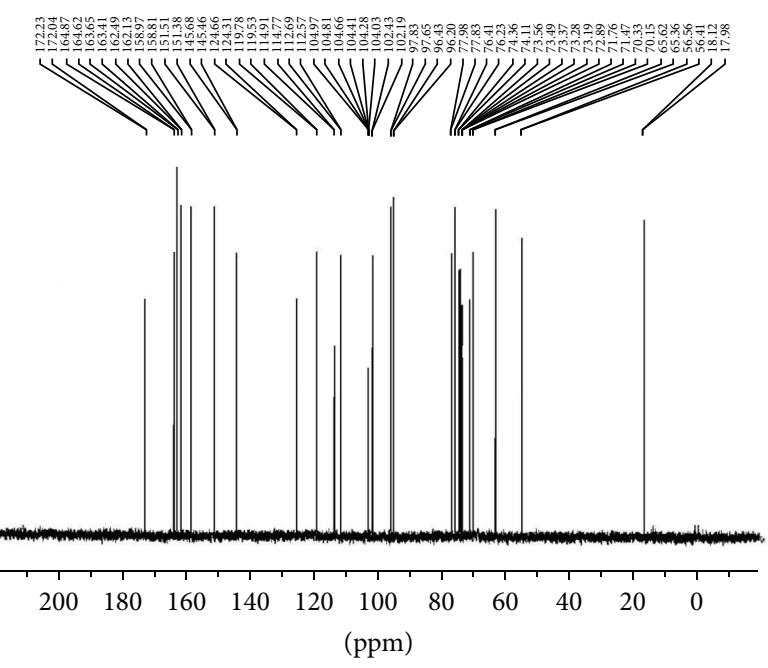

Figure $4:{ }^{13} \mathrm{C}$ NMR of zinc-diosmin complex.

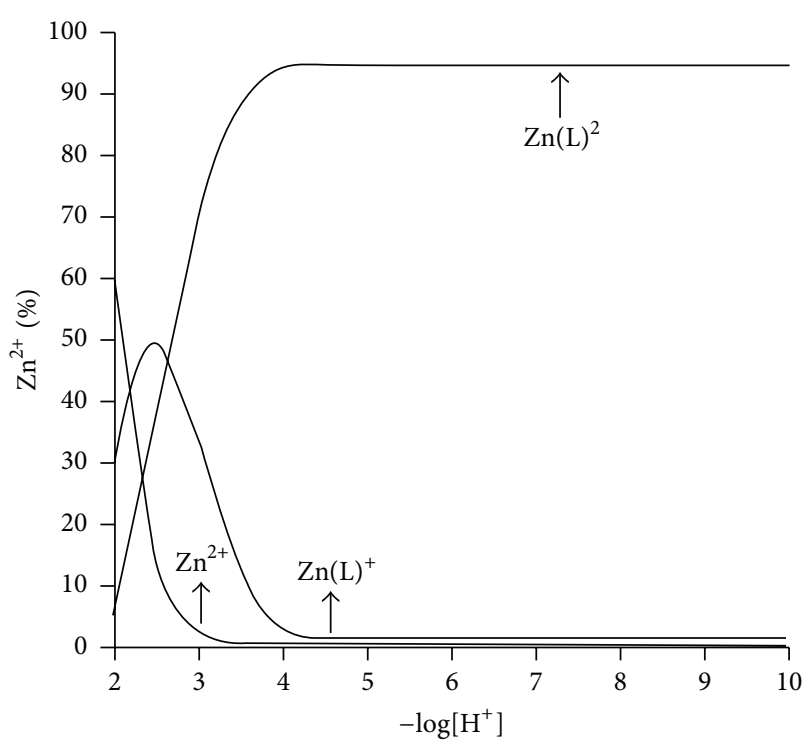

Figure 5: Potentiometric titration studies of zinc-diosmin complex.

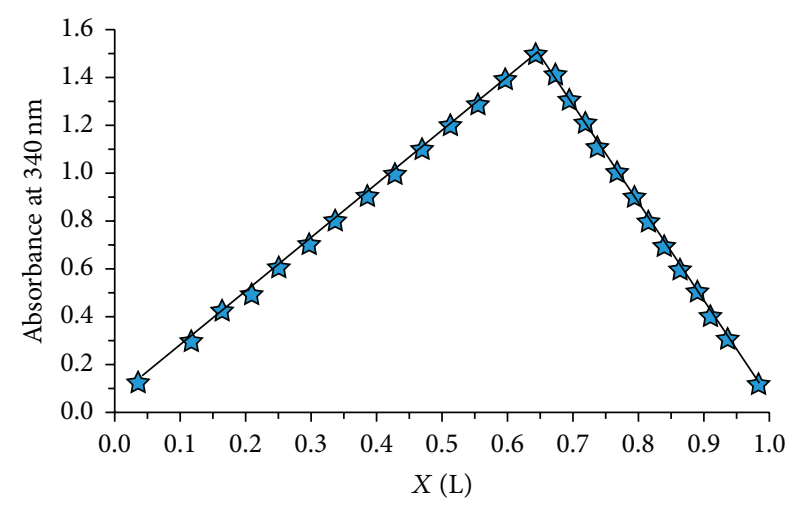

FIGURE 6: Job's plot measurements of zinc-diosmin complex.

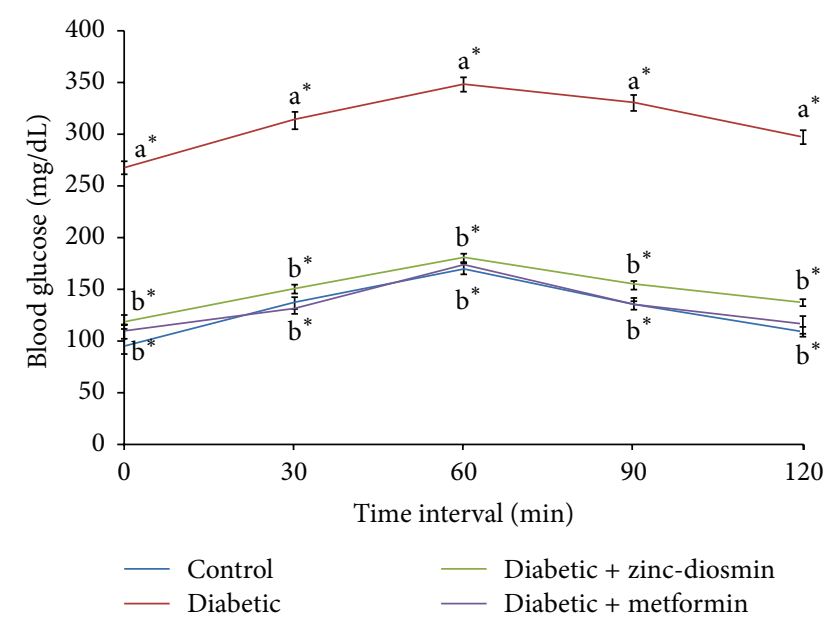

FIGURE 7: Effect of zinc-diosmin complex on oral glucose tolerance in the experimental groups of rats. Results are expressed as mean \pm SEM $[n=6]$. One-way ANOVA followed by post hoc test LSD was done. The results were compared with ${ }^{\mathrm{a}}$ Control rats and ${ }^{\mathrm{b}}$ Diabetic rats. Values are statistically significant at $P<0.05$.

$$
\begin{array}{cc}
\mathrm{Zn}(\mathrm{L})^{+}+\mathrm{L}^{-} \rightleftharpoons \mathrm{Zn}(\mathrm{L})_{2} & \log K_{2}=8.42 \\
\mathrm{Zn}^{2+}+2\left(\mathrm{~L}^{-}\right) \rightleftharpoons \mathrm{Zn}(\mathrm{L})_{2} & \log \beta=18.28
\end{array}
$$

Job's plot measurements were carried out to analyze the complexation ratio between zinc ion and ligand by altering the concentration of both the $\mathrm{Zn}^{2+}$ ions and ligand (Figure 6). The maximum point appears at the mole fraction of 0.65 , close to the typical ligand mole fraction of 0.66 for a $2: 1$ ligand to metal complex, which is in accordance with our recent report [27].

Figure 7 shows the effect of zinc-diosmin complex on the levels of blood glucose in certain durations after the oral administration of glucose $(2 \mathrm{~g} / \mathrm{kg}$ b.w.) in control and experimental groups of rats. The fasting blood glucose level of diabetic rats was significantly higher when compared to control group of rats. Subsequent to oral glucose load, blood glucose levels in HFD-STZ-diabetic rats reached a peak at $60 \mathrm{~min}$ and did not come back to the normal basal level over the next $60 \mathrm{~min}$. In control rats, the blood glucose level reached the maximum peak at $60 \mathrm{~min}$ after 
TABLE 1: The levels of blood glucose, glycosylated hemoglobin (HbAlc), plasma insulin, and urine sugar in control and experimental groups of rats.

\begin{tabular}{|c|c|c|c|c|c|}
\hline Groups & Blood glucose & HbAlc & Insulin & C-peptide & Urine sugar \\
\hline Control & $95.75 \pm 6.04$ & $4.51 \pm 0.29$ & $15.41 \pm 0.27$ & $0.25 \pm 0.023$ & Nil \\
\hline Diabetic control & $268.16 \pm 9.97^{\mathrm{a} *}$ & $10.87 \pm 0.43^{\mathrm{a} *}$ & $10.28 \pm 0.43^{\mathrm{a} *}$ & $0.11 \pm 0.007^{\mathrm{a} *}$ & +++ \\
\hline Diabetic + Zn-diosmin & $118.69 \pm 4.57^{\mathrm{b} *}$ & $6.23 \pm 0.32^{\mathrm{b} *}$ & $13.07 \pm 0.55^{\mathrm{b \#}}$ & $0.17 \pm 0.010^{\mathrm{b} *}$ & Nil \\
\hline Diabetic + metformin & $109.47 \pm 5.40^{\mathrm{b} *}$ & $5.79 \pm 0.97^{\mathrm{b} *}$ & $13.82 \pm 0.47^{\mathrm{b \#}}$ & $0.19 \pm 0.012^{\mathrm{b} *}$ & Nil \\
\hline
\end{tabular}

Units are expressed as $\mathrm{mg} / \mathrm{dL}$ for blood glucose, \% hemoglobin for HbAlc, $\mu \mathrm{U} / \mathrm{mL}$ for plasma insulin, and $\mathrm{pmol} / \mathrm{mL}$ for plasma C-peptide; +++ indicates more than $2 \%$ sugar.

Results are expressed as mean $\pm \operatorname{SEM}[n=6]$. One-way ANOVA followed by post hoc test LSD was done. Values are statistically significant at ${ }^{\#} P<0.01 ;{ }^{*} P<$ 0.001 . The results were ${ }^{\mathrm{a}}$ compared to control rats and ${ }^{\mathrm{b}}$ compared to diabetic rats.

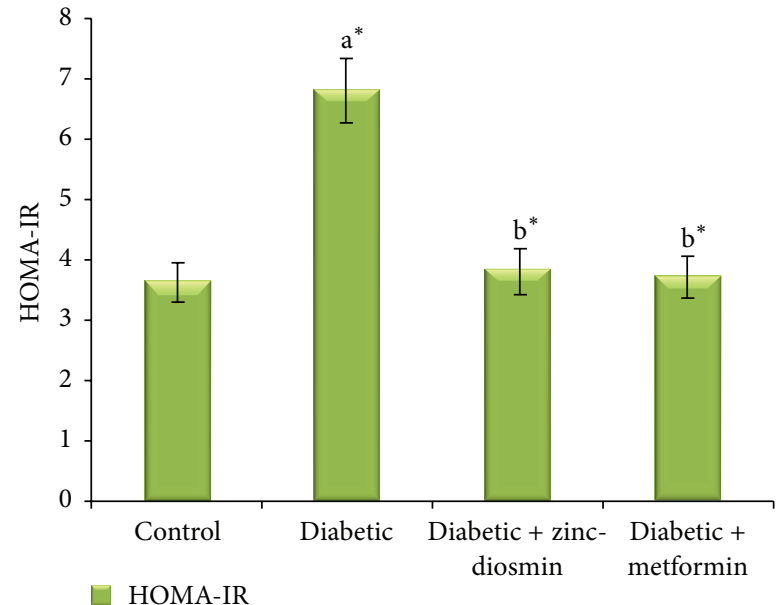

FIGURE 8: Effect of zinc-diosmin complex on insulin sensitivity in experimental groups of rats. Results are expressed as mean \pm SEM $[n=6]$. One-way ANOVA followed by post hoc test LSD was done. The results were compared with ${ }^{\mathrm{a}}$ Control rats and ${ }^{\mathrm{b}}$ Diabetic rats. Values are statistically significant at $P<0.05$.

an oral glucose load and then it was gradually reverted back to near normal after $120 \mathrm{~min}$. Diabetic rats treated with zinc-diosmin complex as well as metformin resulted in a significant reduction in concentration of blood glucose at 0 (fasting), 30, and 60 min compared with untreated HFDSTZ-diabetic rats. In addition, zinc-diosmin complex as well as metformin treated diabetic rats showed blood glucose levels returned to basal value at $120 \mathrm{~min}$ after the oral glucose load. HOMA-IR values of control, diabetic, and diabetic rats treated with zinc-diosmin complex are depicted in Figure 8. Diabetic rats showed a significant elevation of HOMA-IR that was decreased significantly upon treatment with oral administration of complex as well as metformin.

Table 1 depicts the levels of fasting blood glucose, glycosylated hemoglobin, and plasma insulin and the inference for the presence of urine sugar in all groups of experimental rats. Diabetic rats showed significantly elevated levels of fasting glucose and glycosylated hemoglobin and the levels were significantly reduced in zinc-diosmin complex treated diabetic rats. Plasma insulin and C-peptide levels in the diabetic rats are markedly reduced when compared with control rats whereas these altered levels were significantly
TABLE 2: Effect of Zn-diosmin complex on glycogen content in liver and muscle tissues of control and experimental groups of rats.

\begin{tabular}{lcc}
\hline Groups & Liver glycogen & Muscle glycogen \\
\hline Control & $42.29 \pm 1.83$ & $9.48 \pm 0.30$ \\
Diabetic control & $21.33 \pm 0.72^{\mathrm{a} *}$ & $3.99 \pm 0.18^{\mathrm{a} *}$ \\
Diabetic + Zn-diosmin & $36.14 \pm 1.43^{\mathrm{b} *}$ & $7.32 \pm 0.28^{\mathrm{b} *}$ \\
Diabetic + metformin & $36.59 \pm 1.25^{\mathrm{b} *}$ & $8.39 \pm 0.31^{\mathrm{b} *}$ \\
\hline
\end{tabular}

Units are expressed as $\mathrm{mg}$ of glucose/g wet tissue for glycogen.

Results are expressed as mean $\pm \operatorname{SEM}[n=6]$. One-way ANOVA followed by post hoc test LSD was done. Values are statistically significant at ${ }^{*} P<0.001$. The results were ${ }^{\mathrm{a}}$ compared to control rats and ${ }^{\mathrm{b}}$ compared to diabetic rats.

improved in diabetic rats treated with zinc-diosmin complex as well as metformin. Urine sugar was present in diabetic rats. However, after 30 days of treatment with zinc-diosmin complex as well as metformin, urine sugar was no longer detected.

The liver and muscle glycogen content in control and experimental groups of rats are represented in Table 2. The glycogen contents in liver and muscle tissues were significantly decreased in diabetic rats when compared with control rats and the levels were brought back near normal after treatment with zinc-diosmin complex. The diabetic rats treated with metformin also showed significantly improved glycogen content in liver and muscle tissues. Table 3 shows the levels of plasma protein, blood urea, and serum creatinine in control and experimental groups of rats. The increased levels of renal tissue markers such as urea and creatinine and reduced levels of plasma protein in diabetic rats were significantly altered in zinc-diosmin treated diabetic rats. Metformin treated diabetic rats also showed similar improvement in the levels of blood urea, serum creatinine, and plasma protein. The activities of pathophysiological enzymes such as AST, ALT, and ALP in the serum of control and experimental groups of rats are shown in Table 4. Diabetic control rats showed elevated activities of these enzymes when compared with control rats and the elevated activities were reduced significantly in diabetic rats treated with zincdiosmin complex. Similar observations were recorded in the diabetic rats treated with metformin.

The activities of glycogen synthase and glycogen phosphorylase in the liver tissue of control and experimental groups of rats are represented in Table 5. Diabetic rats showed a significant decline in the glycogen synthase activity and a 
TABLE 3: Effect of Zn-diosmin complex on plasma protein and blood urea and serum creatinine levels in rats after 30-day treatment.

\begin{tabular}{lccc}
\hline Groups & Plasma protein & Blood urea & Serum creatinine \\
\hline Control & $8.88 \pm 0.19$ & $25.28 \pm 0.90$ & $0.60 \pm 0.02$ \\
Diabetic control & $6.46 \pm 0.1^{\mathrm{a*}}$ & $45.10 \pm 1.56^{\mathrm{a} *}$ & $1.38 \pm 0.02^{\mathrm{a} *}$ \\
Diabetic + Zn-diosmin & $7.42 \pm 0.12^{\mathrm{b} *}$ & $29.33 \pm 0.96^{\mathrm{b} *}$ & $0.75 \pm 0.01^{\mathrm{b} *}$ \\
Diabetic + metformin & $8.21 \pm 0.17^{\mathrm{b} *}$ & $27.33 \pm 0.75^{\mathrm{b} *}$ & $0.68 \pm 0.02^{\mathrm{b} *}$ \\
\hline
\end{tabular}

Units are expressed as $\mathrm{g} / \mathrm{dL}$ for plasma protein, $\mathrm{mg} / \mathrm{dL}$ for blood urea, and serum creatinine.

Values are given as mean \pm SEM for groups of six rats in each. One-way ANOVA followed by post hoc test LSD was done. Values are statistically significant at ${ }^{*} P<0.001$. The results were ${ }^{\mathrm{a}}$ compared to control rats and ${ }^{\mathrm{b}}$ compared to diabetic rats.

TABLE 4: Effect of Zn-diosmin complex on levels of activities of AST, ALT, and ALP in the serum of control and experimental groups of rats.

\begin{tabular}{lccc}
\hline Groups & AST & ALT & ALP \\
\hline $\begin{array}{l}\text { Control } \\
\begin{array}{l}\text { Diabetic } \\
\text { control }\end{array}\end{array}$ & $131.06 \pm 2.28$ & $21.27 \pm 0.63$ & $72.45 \pm 0.85$ \\
$\begin{array}{l}\text { Diabetic }+ \\
\begin{array}{l}\text { Zn-diosmin } \\
\text { Diabetic }+\end{array}\end{array}$ & $83.94 \pm 2.28^{\mathrm{a} *}$ & $24.51 \pm 1.01^{\mathrm{b} *}$ & $93.85 \pm 2.05^{\mathrm{b} *}$ \\
metformin & $71.39 \pm 1.90^{\mathrm{b} *}$ & $21.14 \pm 0.94^{\mathrm{b} *}$ & $71.75 \pm 1.74^{\mathrm{b} *}$ \\
\hline
\end{tabular}

Enzyme activities are expressed as AST and ALT - 1 moles of pyruvate liberated/h/mg of protein, ALP - 1 moles of phenol liberated/min/mg of protein.

Results are expressed as mean \pm SEM $[n=6]$. One-way ANOVA followed by post hoc test LSD was done. Values are statistically significant at ${ }^{*} P<0.001$. The results were ${ }^{\mathrm{a}}$ compared to control rats and ${ }^{\mathrm{b}}$ compared to diabetic rats.

TABLE 5: The activities of glycogen synthase and glycogen phosphorylase in liver tissues of control and experimental groups of rats.

\begin{tabular}{|c|c|c|}
\hline Groups & $\begin{array}{l}\text { Glycogen } \\
\text { synthase }\end{array}$ & $\begin{array}{c}\text { Glycogen } \\
\text { phosphorylase }\end{array}$ \\
\hline Control & $829.61 \pm 20.42$ & $513.56 \pm 25.67$ \\
\hline $\begin{array}{l}\text { Diabetic } \\
\text { control }\end{array}$ & $439.45 \pm 15.64^{\mathrm{a} *}$ & $783.63 \pm 22.63^{\mathrm{a} *}$ \\
\hline $\begin{array}{l}\text { Diabetic + } \\
\text { Zn-diosmin }\end{array}$ & $667.13 \pm 16.66^{\mathrm{b} *}$ & $659.16 \pm 14.69^{\mathrm{b} *}$ \\
\hline $\begin{array}{l}\text { Diabetic + } \\
\text { metformin }\end{array}$ & $690.96 \pm 18.84^{\mathrm{b} *}$ & $633.48 \pm 17.39^{\mathrm{b} *}$ \\
\hline
\end{tabular}

Units are expressed as $\mu$ moles of UDP formed $/ \mathrm{h} / \mathrm{mg}$ protein for glycogen synthase and $\mu$ moles Pi liberated $/ \mathrm{h} / \mathrm{mg}$ protein for glycogen phosphorylase. Results are expressed as mean \pm SEM $[n=6]$. One-way ANOVA followed by post hoc test LSD was done. Values are statistically significant at ${ }^{*} P<0.001$. The results were ${ }^{a}$ compared to control rats and ${ }^{b}$ compared to diabetic rats.

concomitant increase in the activity of glycogen phosphorylase. Oral administration of zinc-diosmin complex as well as metformin to HFD-STZ diabetic rats restored the activities of glycogen synthase and glycogen phosphorylase.

\section{Discussion}

The binding mode of diosmin to zinc ions was studied by comparing the IR spectrum of free diosmin with the spectrum of zinc-diosmin complex. The $\alpha$-hydroxycarbonyl group of flavonoids was reported as the preferential site for the binding of the metal ions. The peaks observed at 1676 and $3435\left(v \mathrm{~cm}^{-1}\right)$ correspond to the presence of carbonyl and hydroxyl groups in the free ligand, respectively. These bands have undergone a shift to a lower frequency [1653 and 3354 $\left.\left(\nu \mathrm{cm}^{-1}\right)\right]$ after complexation, indicating the coordination of the hydroxyl and carbonyl groups with the zinc ion. The nature of bonding was further confirmed by a newly formed band at $502 \mathrm{~cm}^{-1}$ in the spectrum of the complex, which is tentatively assigned to $\mathrm{M}-\mathrm{O}$ vibration. In both free diosmin and zinc-diosmin complex, the peaks around $1500 \mathrm{~cm}^{-1}$ are due to the presence of $\mathrm{C}=\mathrm{C}$ stretching. This observation is in accordance with an earlier report of Ai et al. [62].

Molecular weight of the synthesized zinc-diosmin complex was confirmed by the molecular ion peak $\left[\mathrm{M}^{+}\right]$at $m / z=1280$. Various fragments $\mathrm{C}_{50} \mathrm{H}_{52} \mathrm{O}_{25} \mathrm{Zn}, \mathrm{C}_{44} \mathrm{H}_{42} \mathrm{O}_{20} \mathrm{Zn}$, $\mathrm{C}_{39} \mathrm{H}_{40} \mathrm{O}_{14} \mathrm{Zn}, \mathrm{C}_{33} \mathrm{H}_{29} \mathrm{O}_{10} \mathrm{Zn}, \mathrm{C}_{26} \mathrm{H}_{17} \mathrm{O}_{8} \mathrm{Zn}$, and $\mathrm{C}_{9} \mathrm{H}_{5} \mathrm{O}_{3} \mathrm{Zn}$ show the peaks at $m / z=1115,953,796,650,523$, and 226, respectively, in mass spectral analysis. Thus, the mass spectra data suggest that the molar fraction of zinc and diosmin in the complex is in the ratio of $1: 2$, which concurs with an earlier report [63].

The ${ }^{1} \mathrm{H}$ NMR studies were carried out on a Bruker AM 500 instrument using $\mathrm{d}_{6}$-DMSO as the solvent. The ${ }^{1} \mathrm{H}$ NMR spectrum of the free diosmin showed 32 proton peaks. Diosmin exhibits a singlet signal at $4.82 \mathrm{ppm}$ corresponding to two aromatic free hydroxyl groups, whereas, in the case of zinc-diosmin complex, instead of four-hydroxyl proton signals only two signals were observed. This clearly evidenced that the deprotonated hydroxyl group is involved in the chelation. Both the free diosmin and zinc-diosmin complex show a peak around $1.4 \mathrm{ppm}$ and $3.7 \mathrm{ppm}$ due to the presence of $-\mathrm{CH}_{3}$ and $-\mathrm{OCH}_{3}$ groups. The aromatic proton peaks were also observed around 5.6-6.9 ppm $(6 \mathrm{H})$. Similarly, the proton signals for saccharide protons were observed in the range of 3.1-5.1 ppm. There are no appreciable changes in the rest of the signals in the synthesized complex [64].

The zinc-diosmin complex as well as the free diosmin was also characterized by means of ${ }^{13} \mathrm{C}$ NMR spectroscopy. The ${ }^{13} \mathrm{C}$ NMR spectra showed similar characteristic features of both free diosmin and zinc-diosmin complex. The peaks assigned to the aromatic carbons were found in the range of 119-164 ppm. The peaks around 65-77 ppm and peak at $18 \mathrm{ppm}$ indicate the presence of glucose moiety carbons and the $\mathrm{CH}_{3}$ carbons, respectively. Likewise, the $-\mathrm{OCH}_{3}$ peak 
was observed around $56 \mathrm{ppm}$. The peaks around 96, 104, and $114 \mathrm{ppm}$ denote the presence of $-\mathrm{CH}$ group present in the benzene ring. Similarly, the presence of the $\mathrm{C}=\mathrm{O}$ signal at about $183 \mathrm{ppm}$ in the spectrum of free diosmin and the absence of this signal in the spectrum of the zincdiosmin complex along with the appearance of a signal at a lower value (172 ppm) supported the evidence that the zincdiosmin complex was formed through carbonyl carbon. Thus, both the ${ }^{1} \mathrm{H}$ NMR and ${ }^{13} \mathrm{C}$ NMR spectroscopic data support the proposed structure of the synthesized complex. The NMR analyses obtained were in accordance with an earlier report [65].

Increasing prevalence of type 2 diabetes worldwide has underscored the necessity of developing an efficient therapeutic agent without any adverse side effect. Recently, increasing attention has been given to the role of certain trace elements in the pathogenesis of diabetes mellitus and its secondary complications. Total zinc content in the pancreatic $\beta$-cells is among the highest in the body and alterations in the $\mathrm{Zn}^{2+}$ level have been found to be associated with diabetes [66]. In order to improve the bioavailability and reduce the toxicity of zinc, several zinc complexes have been synthesized and studied for their insulinomimetic and insulin sensitizing effects. In the present study, diosmin a naturally occurring flavonoid glycoside was used as a ligand to synthesize a new zinc complex. Diosmin is known to regulate glucose metabolism by enhancing the activities of glycolytic enzymes by stimulating the insulin production from the remnant $\beta$ cells of pancreas [67].

Based on the dose-dependent effect of zinc-diosmin complex on the levels of fasting blood glucose concentration, $20 \mathrm{mg} / \mathrm{kg}$ b.w./rat/day for 30 days was fixed as the optimum dosage for evaluating the antidiabetic properties of the complex. High fat diet fed-low dose streptozotocin induced experimental type 2 diabetes in rats is an ideal animal model as it closely resembles the clinical and metabolic characteristics of human type 2 diabetes and widely used for pharmacological screening $[67,68]$. Therefore, it is used in the present study to evaluate the antidiabetic properties of zinc-diosmin complex.

Blood glucose control is an important component in delaying or preventing acute or long-term diabetic complications. Though insulin resistance is the initiating pathogenic factor in type 2 diabetes, $\beta$-cell failure is accountable for insulin deficiency and impaired glucose tolerance to explicit type 2 diabetes [69]. In the present study, an observed low level of plasma insulin in HFD-STZ induced rats indicates perturbations in $\beta$-cell function. Furthermore, the degree of hyperinsulinemia and insulin resistance was substantiated from HOMA-IR values. HFD-STZ rats showed significantly higher HOMA-IR values. Hemoglobin in the circulation binds to glucose under physiological conditions by nonenzymatic, irreversible covalent bonding to form glycosylated hemoglobin (HbAlc). In diabetes, the level of HbAlc is significantly elevated because of increased glycation of hemoglobin due to persistent hyperglycemia. The level of $\mathrm{HbAlc}$ reflects the average blood glucose level over the past 3 months. Thus, $\mathrm{HbAlc} \mathrm{levels} \mathrm{serve} \mathrm{as} \mathrm{a} \mathrm{golden} \mathrm{marker} \mathrm{for} \mathrm{the} \mathrm{diagnosis} \mathrm{as} \mathrm{well}$ as prognosis of diabetes mellitus. The significant reduction in the level of HbAlc in zinc-diosmin complex treated diabetic rats may be due to the maintenance of normal glucose homeostasis which is further evidenced from the results of OGTT and FBG. Significant reduction in the HOMA-IR indices of zinc-diosmin complex treated rats also indicates the efficacy of the complex in restoring insulin sensitivity.

Previous studies indicate that oral administration of dios$\mathrm{min}$ at a concentration of $100 \mathrm{mg} / \mathrm{kg}$ b.w./rat/day for 30 days significantly reduced the blood glucose levels and controlled the secondary complications in STZ-nicotinamide induced experimental diabetes in rats. Though the dosage fixed in the present study for the treatment of diabetes is $20 \mathrm{mg} / \mathrm{kg} \mathrm{b.w}$. of zinc-diosmin complex, the results are comparable with the efficacy of the diosmin used in the earlier studies $[38,70]$.

Under normal physiological conditions, the excess glucose is stored in the form of glycogen mainly in liver and muscle tissues. However, the levels of intracellular glycogen deposition were reduced in diabetes because of diminished insulin activity, as insulin facilitates intracellular glycogen storage by inhibiting the activity of glycogen phosphorylase and stimulating the activity of glycogen synthase [71]. The glycogen contents in liver and muscle tissues were reduced in HFD-STZ induced type 2 diabetic rats. However, upon treatment with zinc-diosmin complex, the glycogen content was increased indicating the improved insulin sensitivity in the liver and muscle tissues.

The presence of elevated levels of intracellular enzymes such as transaminases and serum alkaline phosphatase in the circulation is the most sensitive and dramatic indicators of hepatic cell injury. During tissue damage, these soluble enzymes are leached out from the cells and their activities were found to be increased in the serum [72]. Elevated levels of these enzymes were also an indication of cellular damage and functional integrity loss of the cell membranes. A strong association exists among serum ALT level and HOMA-IR scores but not for the AST level and it has been indicated as an interpreter of type 2 diabetes in humans [73]. The increased activities of hepatocellular marker enzymes such as AST, ALT, and ALP in diabetic rats were reduced significantly upon treatment with zinc-diosmin complex indicating the nontoxic and tissue protective nature of the complex.

The metabolism of proteins is abnormal in HFD-STZ induced type 2 diabetes due to enhanced insulin resistance and muscle wasting. This ultimately results in profound increase in protein catabolism and significant reduction in protein synthesis [74]. The imbalance between anabolism and catabolism of proteins causes remarkable effects in the metabolic functions of renal tissues. Disturbances in renal function cause elevated levels of blood urea and serum creatinine, because urea is the main end product of protein catabolism and creatinine is a byproduct formed by the breakdown of creatine and phosphocreatine, which are considered as energy storage compounds in muscle tissues. The elevated levels of blood urea and serum creatinine suggest abnormality in the renal tissue to excrete urea and creatinine. The levels of these markers were significantly decreased in complex treated diabetic rats indicating the beneficial effect of the complex in ameliorating diabetes associated renal complications. 


\section{Conclusion}

In conclusion, the present study reveals the formation of complex between zinc ions and diosmin and its characterization by various spectral studies, $\mathrm{pH}$-potentiometric titrations, and Job's plot. Oral administration of zinc-diosmin complex to HFD-STZ induced type 2 diabetic rats restored the activities of hepatocellular marker enzymes exemplifying the nontoxic nature of the complex. In addition, zinc-diosmin complex treatment leads to improved insulin sensitivity, at least in part, through improving protein metabolism and alterations in the levels of muscle and liver glycogen. These findings suggest that zinc-diosmin complex has complimentary potency to develop as an antihyperglycemic drug for the treatment of diabetes and its secondary complications. Further studies are in progress to elicit the molecular mechanisms involved in the antihyperglycemic action of zinc-diosmin complex in maintaining normoglycemia in type 2 diabetes mellitus.

\section{Conflict of Interests}

The authors declare that they have no conflict of interests.

\section{Acknowledgment}

The research fellowship awarded by the University Grants Commission, Government of India, to Mr. V. Gopalakrishnan (GCCO/A-2/UGC-MERITORIOUS/2013/378 dated 28.05.2013) is gratefully acknowledged.

\section{References}

[1] S. Panda and A. Kar, "Antidiabetic and antioxidative effects of Annona squamosa leaves are possibly mediated through quercetin-3-O-glucoside," BioFactors, vol. 31, no. 3-4, pp. 201210, 2007.

[2] M. E. Cerf, "Beta cell dysfunction and insulin resistance," Frontiers in Endocrinology, vol. 4, article 37, 2013.

[3] L. Guariguata, D. R. Whiting, I. Hambleton, J. Beagley, U. Linnenkamp, and J. E. Shaw, "Global estimates of diabetes prevalence for 2013 and projections for 2035," Diabetes Research and Clinical Practice, vol. 103, no. 2, pp. 137-149, 2014.

[4] N. S. Levitt, J. M. Katzenellenbogen, D. Brabshaw, M. N. Hoffman, and F. Bonnici, "The prevalence and identification of risk factors for NIDDM in urban Africans in Cape Town, South Africa," Diabetes Care, vol. 16, no. 4, pp. 601-607, 1993.

[5] R. Herring, R. H. Jones, and D. L. Russell-Jones, "Hepatoselectivity and the evolution of insulin," Diabetes, Obesity and Metabolism, vol. 16, no. 1, pp. 1-8, 2014.

[6] J. Mukai, H. Tada, Y. Watanabe et al., "Lipids behavior and adverse effects for oral antidiabetic agents in patients with type 2 diabetes treated with sulfonylureas alone based on systematic review," Yakugaku Zasshi, vol. 127, no. 10, pp. 1747-1756, 2007.

[7] A. Katoh, Y. Matsumura, Y. Yoshikawa, H. Yasui, and H. Sakurai, "Evaluation of insulin-mimetic activities of vanadyl and zinc(II) complexes from the viewpoint of heterocyclic bidentate ligands," Journal of Inorganic Biochemistry, vol. 103, no. 4, pp. 567-574, 2009.

[8] A. R. Marita and K. L. Anilkumar, "Effect of vanadate on glycogen synthesis in dexamethasone-treated 3T3 adipocytes: evidence for a novel insulin sensitizing action," Diabetes, Obesity and Metabolism, vol. 3, no. 4, pp. 271-278, 2001.

[9] M. C. Muñoz, A. Barberà, J. Domínguez, J. Fernàndez-Alvarez, R. Gomis, and J. J. Guinovart, "Effects of tungstate, a new potential oral antidiabetic agent, in Zucker diabetic fatty rats," Diabetes, vol. 50, no. 1, pp. 131-138, 2001.

[10] H. Sakurai, "The discovery of vanadyl and zinc complexes for treating diabetes and metabolic syndromes," Expert Opinion on Drug Discovery, vol. 2, no. 6, pp. 873-887, 2007.

[11] J. Meyerovitch, Z. Farfel, J. Sack, and Y. Shechter, "Oral administration of vanadate normalizes blood glucose levels in streptozotocin-treated rats. Characterization and mode of action," The Journal of Biological Chemistry, vol. 262, no. 14, pp. 6658-6662, 1987.

[12] R. Jayawardena, P. Ranasinghe, P. Galappatthy, R. L. D. K. Malkanthi, G. R. Constantine, and P. Katulanda, "Effects of zinc supplementation on diabetes mellitus: a systematic review and meta-analysis," Diabetology and Metabolic Syndrome, vol. 4, article 13, 2012.

[13] D. A. Scott, "Crystalline insulin," Biochemical Journal, vol. 28, no. 4, pp. 1592-1602.1, 1934.

[14] L. Coulston and P. Dandona, "Insulin-like effect of zinc on adipocytes," Diabetes, vol. 29, no. 8, pp. 665-667, 1980.

[15] S. Frassinetti, G. L. Bronzetti, L. Caltavuturo, M. Cini, and C. D. Croce, "The role of zinc in life: a review," Journal of Environmental Pathology, Toxicology and Oncology, vol. 25, no. 3, pp. 597-610, 2006.

[16] B. L. Vallee and K. H. Falchuk, "The biochemical basis of zinc physiology," Physiological Reviews, vol. 73, no. 1, pp. 79-118, 1993.

[17] S. O. Emdin, G. G. Dodson, J. M. Cutfield, and S. M. Cutfield, "Role of zinc in insulin biosynthesis. Some possible zinc-insulin interactions in the pancreatic B-cell," Diabetologia, vol. 19, no. 3, pp. 174-182, 1980.

[18] D. Özcelik, M. Nazıroglu, M. Tunçdemir, Ö. Çelik, M. Öztürk, and M. F. Flores-Arce, "Zinc supplementation attenuates metallothionein and oxidative stress changes in kidney of streptozotocin-induced diabetic rats," Biological Trace Element Research, vol. 150, no. 1-3, pp. 342-349, 2012.

[19] Y. Liu, B. Batchuluun, L. Ho et al., "Characterization of zinc influx transporters (ZIPs) in pancreatic $\beta$ cells," Journal of Biological Chemistry, vol. 290, no. 30, pp. 18757-18769, 2015.

[20] Y. V. Li, "Zinc and insulin in pancreatic beta-cells," Endocrine, vol. 45, no. 2, pp. 178-189, 2014.

[21] M. Galanski, M. A. Jakupec, and B. K. Keppler, "Update of the preclinical situation of anticancer platinum complexes: novel design strategies and innovative analytical approaches," Current Medicinal Chemistry, vol. 12, no. 18, pp. 2075-2094, 2005.

[22] E. J. Corey, M. M. Mehrotra, and A. U. Khan, "Antiarthritic gold compounds effectively quench electronically excited singlet oxygen," Science, vol. 236, no. 4797, pp. 68-69, 1987.

[23] Y. Yoshikawa, "Development research of new Zn complexes with anti-diabetic effect-structure-activity-related studies by displacement of coordination atom," Yakugaku Zasshi, vol. 132, no. 9, pp. 1051-1055, 2012

[24] H. Sakurai and Y. Adachi, "The pharmacology of the insulinomimetic effect of zinc complexes," BioMetals, vol. 18, no. 4, pp. 319-323, 2005.

[25] K. Vijayaraghavan, S. I. Pillai, and S. P. Subramanian, "Design, synthesis and characterization of zinc-3 hydroxy flavone, a novel zinc metallo complex for the treatment of experimental diabetes in rats," European Journal of Pharmacology, vol. 680, no. 1-3, pp. 122-129, 2012. 
[26] V. Sendrayaperumal, S. Iyyam Pillai, and S. Subramanian, "Design, synthesis and characterization of zinc-morin, a metal flavonol complex and evaluation of its antidiabetic potential in HFD-STZ induced type 2 diabetes in rats," Chemico-Biological Interactions, vol. 219, pp. 9-17, 2014.

[27] J. Uma Maheswari, S. Iyyam Pillai, and S. P. Subramanian, "Zinc-silibinin complex: synthesis, spectral characterization and biochemical evaluation of antidiabetic potential in high fat fed low dose STZ induced type 2 diabetic rats," Journal of Chemical and Pharmaceutical Research, vol. 7, no. 3, pp. 20512064, 2015.

[28] B. H. Havsteen, "The biochemistry and medical significance of the flavonoids," Pharmacology and Therapeutics, vol. 96, no. 2-3, pp. 67-202, 2002.

[29] C. A. Rice-Evans, N. J. Miller, and G. Paganga, "Structureantioxidant activity relationships of flavonoids and phenolic acids," Free Radical Biology and Medicine, vol. 20, no. 7, pp. 933956, 1996.

[30] J. P. Cornard and J. C. Merlin, "Comparison of the chelating power of hydroxyflavones," Journal of Molecular Structure, vol. 651-653, pp. 381-387, 2003.

[31] M. A. Campanero, M. Escolar, G. Perez, E. Garcia-Quetglas, B. Sadaba, and J. R. Azanza, "Simultaneous determination of diosmin and diosmetin in human plasma by ion trap liquid chromatography-atmospheric pressure chemical ionization tandem mass spectrometry: application to a clinical pharmacokinetic study," Journal of Pharmaceutical and Biomedical Analysis, vol. 51, no. 4, pp. 875-881, 2010.

[32] O. A. Oesterle and G. Wander, "Naturally occurring flavonic glycoside; rhamnoglycoside of diosmetin, q.v. Isolation from various plant sources," Helvetica Chimica Acta, vol. 8, article 519, 1925.

[33] G. Hitzenberger, "Therapeutic effectiveness of flavonoids illustrated by daflon $500 \mathrm{mg}$," Wiener Medizinische Wochenschrift, vol. 147, no. 18, pp. 409-412, 1997.

[34] W. Thanapongsathorn and T. Vajrabukka, "Clinical trial of oral diosmin (Daflon) in the treatment of hemorrhoids," Diseases of the Colon and Rectum, vol. 35, no. 11, pp. 1085-1088, 1992.

[35] A. K. Ratty and N. P. Das, "Effects of flavonoids on nonenzymatic lipid peroxidation: structure-activity relationship," Biochemical Medicine and Metabolic Biology, vol. 39, no. 1, pp. 6979, 1988.

[36] T. Tanaka, H. Kohno, and H. Mori, "Chemoprevention of colon carcinogenesis by dietary non-nutritive compounds," Asian Pacific Journal of Cancer Prevention, vol. 2, no. 3, pp. 165-177, 2001.

[37] M. Tahir, M. U. Rehman, A. Lateef et al., "Diosmin protects against ethanol-induced hepatic injury via alleviation of inflammation and regulation of TNF- $\alpha$ and NF- $\kappa$ B activation," Alcohol, vol. 47, no. 2, pp. 131-139, 2013.

[38] S. Srinivasan and L. Pari, "Ameliorative effect of diosmin, a citrus flavonoid against streptozotocin-nicotinamide generated oxidative stress induced diabetic rats," Chemico-Biological Interactions, vol. 195, no. 1, pp. 43-51, 2012.

[39] J. P. Cornard, L. Vrielynck, J. C. Merlin, and J. C. Wallet, "Structural and vibrational study of 3-hydroxyflavone and 3methoxyflavone," Spectrochimica Acta Part A: Molecular and Biomolecular Spectroscopy, vol. 51, no. 5, pp. 913-923, 1995.

[40] H.-X. Zhang and P. Mei, "Synthesis of morin-zinc(II) complex and its interaction with serum albumin," Biological Trace Element Research, vol. 143, no. 2, pp. 677-687, 2011.
[41] J. Tan, B. Wang, and L. Zhu, "DNA binding, cytotoxicity, apoptotic inducing activity, and molecular modeling study of quercetin zinc(II) complex," Bioorganic and Medicinal Chemistry, vol. 17, no. 2, pp. 614-620, 2009.

[42] N. E. Ikeda, E. M. Novak, D. A. Maria, A. S. Velosa, and R. M. Pereira, "Synthesis, characterization and biological evaluation of Rutin-zinc(II) flavonoid-metal complex," Chemico-Biological Interactions, vol. 239, pp. 184-191, 2015.

[43] K. H. Thompson, B. D. Liboiron, Y. Sun et al., "Preparation and characterization of vanadyl complexes with bidentate maltoltype ligands; in vivo comparisons of anti-diabetic therapeutic potential," Journal of Biological Inorganic Chemistry, vol. 8, no. 1-2, pp. 66-74, 2003.

[44] Z. Vargová, J. Kotek, J. Rudovský et al., “Ternary complexes of zinc(II), cyclen and pyridinecarboxylic acids," European Journal of Inorganic Chemistry, no. 25, pp. 3974-3987, 2007.

[45] K. Srinivasan, B. Viswanad, L. Asrat, C. L. Kaul, and P. Ramarao, "Combination of high-fat diet-fed and low-dose streptozotocintreated rat: a model for type 2 diabetes and pharmacological screening," Pharmacological Research, vol. 52, no. 4, pp. 313-320, 2005.

[46] E. Bartoli, G. P. Fra, and G. P. C. Schianca, "The oral glucose tolerance test (OGTT) revisited," European Journal of Internal Medicine, vol. 22, no. 1, pp. 8-12, 2011.

[47] D. R. Matthews, J. P. Hosker, A. S. Rudenski, B. A. Naylor, D. F. Treacher, and R. C. Turner, "Homeostasis model assessment: insulin resistance and beta-cell function from fasting plasma glucose and insulin concentrations in man," Diabetologia, vol. 28, no. 7, pp. 412-419, 1985.

[48] W. Hassid and S. Abraham, "Chemical procedures for analysis of polysaccharides," in Methods in Enzymology, S. Colowick and N. Kaplan, Eds., vol. 3, pp. 34-36, Academic Press, New York, NY, USA, 1957.

[49] P. Trinder, "Determination of blood glucose using an oxidaseperoxidase system with a non-carcinogenic chromogen," Journal of Clinical Pathology, vol. 22, no. 2, pp. 158-161, 1969.

[50] S. S. Nayak and T. N. Pattabiraman, "A new colorimetric method for the estimation of glycosylated hemoglobin," Clinica Chimica Acta, vol. 109, no. 3, pp. 267-274, 1981.

[51] O. H. Lowry, N. J. Rosebrough, A. L. Farr, and R. J. Randall, "Protein measurement with the Folin phenol reagent," The Journal of Biological Chemistry, vol. 193, no. 1, pp. 265-275, 1951.

[52] M. L. Scott and C. Beffa, "A rapid method for the estimation of urea in biologic fluids," American Journal of Clinical Ppathology, vol. 21, no. 3, pp. 275-281, 1951.

[53] J. Brod and J. H. Sirota, "The renal clearance of endogenous 'creatinine' in man," Journal of Clinical Investigation, vol. 27, no. 5, pp. 645-654, 1948.

[54] J. King, “Transaminases: alanine and aspartate transaminases," in Practical Clinical Enzymology, pp. 363-395, D. Van Nostrand Company, London, UK, 1965.

[55] J. King, "The hydrolases-acid and alkaline phosphatases," in Practical Clinical Enzymology, pp. 199-208, D. Van Nostrand Company, London, UK, 1965.

[56] L. F. Leloir and S. H. Goldemberg, "Glycogen synthetase from rat liver," in Methods in Enzymology, S. P. Colowick and N. O. Kaplan, Eds., vol. 5, pp. 145-146, Academic Press, New York, NY, USA, 1962.

[57] M. Cornblath, P. J. Randle, A. Parmeggiani, and H. E. Morgan, "Regulation of glycogenolysis in muscle. Effects of glucagon and 
anoxia on lactate production, glycogen content, and phosphorylase activity in the perfused isolated rat heart," The Journal of Biological Chemistry, vol. 238, pp. 1592-1597, 1963.

[58] M. L. Godino-Salido, M. D. Gutiérrez-Valero, R. López-Garzón, and J. M. Moreno-Sánchez, " $\mathrm{Zn}$ (II) complexes with thiopyrimidine derivatives: solution study, synthesis and crystal structure of a zig-zag chain zinc(II) complex with the ligand 4,6dimethyl-2-thiopyrimidine," Inorganica Chimica Acta, vol. 221, no. 1-2, pp. 177-181, 1994.

[59] J.-S. Choi, J. J. Braymer, S. K. Park, S. Mustafa, J. Chae, and M. H. Lim, "Synthesis and characterization of IMPY derivatives that regulate metal-induced amyloid- $\beta$ aggregation," Metallomics, vol. 3, no. 3, pp. 284-291, 2011.

[60] J. J. Braymer, J.-S. Choi, A. S. Detoma et al., "Development of bifunctional stilbene derivatives for targeting and modulating metal-amyloid- $\beta$ species," Inorganic Chemistry, vol. 50, no. 21, pp. 10724-10734, 2011.

[61] V. G. Yuen, P. Caravan, L. Gelmini et al., "Glucose-lowering properties of vanadium compounds: comparison of coordination complexes with maltol or kojic acid as ligands," Journal of Inorganic Biochemistry, vol. 68, no. 2, pp. 109-116, 1997.

[62] F. Ai, Y. Ma, J. Wang, and Y. Li, "Preparation, physicochemical characterization and in-vitro dissolution studies of diosmincyclodextrin inclusion complexes," Iranian Journal of Pharmaceutical Research, vol. 13, no. 4, pp. 1115-1123, 2014.

[63] F. Hernandez Hernandez, J. Medina Escriche, and M. T. Gasco Andreu, "Enhancement of the fluorescence of the zinc-morin complex by a non-ionic surfactant," Talanta, vol. 33, no. 6, pp. 537-540, 1986.

[64] J. L. Nieto and A. M. Gutierrez, " ${ }^{1} \mathrm{H}$ NMR spectra at $360 \mathrm{MHz}$ of diosmin and hesperidin in DMSO solution," Spectroscopy Letters, vol. 19, no. 5, pp. 427-434, 1986.

[65] R. K. Markham and V. M. Chari, "Carbon-13 NMR spectroscopy of flavonoids," in The Flavonoids, pp. 19-134, Springer, New York, NY, USA, 1982.

[66] D. A. Scott and A. M. Fisher, "The insulin and the zinc content of normal and diabetic pancreas," The Journal of Clinical Investigation, vol. 17, no. 6, pp. 725-728, 1938.

[67] L. Pari and S. Srinivasan, "Antihyperglycemic effect of diosmin on hepatic key enzymes of carbohydrate metabolism in streptozotocin-nicotinamide-induced diabetic rats, Biomedicine \& Pharmacotherapy, vol. 64, no. 7, pp. 477-481, 2010.

[68] M. J. Reed, K. Meszaros, L. J. Entes et al., "A new rat model of type 2 diabetes: the fat-fed, streptozotocin-treated rat," Metabolism, vol. 49, no. 11, pp. 1390-1394, 2000.

[69] M. A. Abdul-Ghani, D. Tripathy, and R. A. DeFronzo, "Contributions of $\beta$-cell dysfunction and insulin resistance to the pathogenesis of impaired glucose tolerance and impaired fasting glucose," Diabetes Care, vol. 29, no. 5, pp. 1130-1139, 2006.

[70] D. Jain, M. K. Bansal, R. Dalvi, A. Upganlawar, and R. Somani, "Protective effect of diosmin against diabetic neuropathy in experimental rats," Journal of Integrative Medicine, vol. 12, no. 1, pp. 35-41, 2014.

[71] B. A. Pederson, J. M. Schroeder, G. E. Parker, M. W. Smith, A. A. DePaoli-Roach, and P. J. Roach, "Glucose metabolism in mice lacking muscle glycogen synthase," Diabetes, vol. 54, no. 12, pp. 3466-3473, 2005.

[72] E. H. Harris, "Elevated liver function tests in type 2 diabetes," Clinical Diabetes, vol. 23, no. 3, pp. 115-119, 2005.

[73] N. H. Cho, H. C. Jang, H. C. Sung et al., "Abnormal liver function test predicts type 2 diabetes: a community-based prospective study," Diabetes Care, vol. 30, no. 10, pp. 2566-2568, 2007.

[74] N. Møller and K. S. Nair, "Diabetes and protein metabolism," Diabetes, vol. 57, no. 1, pp. 3-4, 2008. 

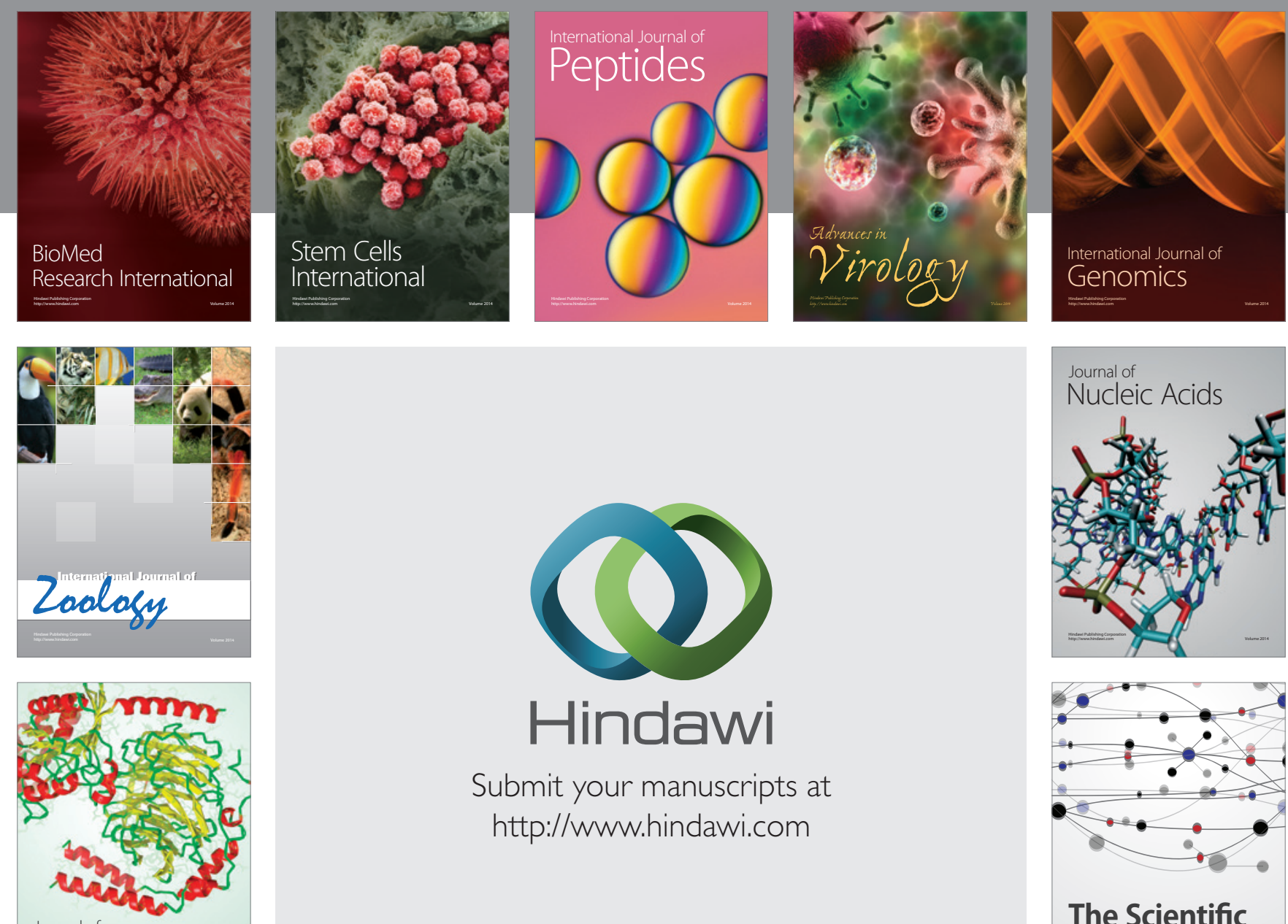

Submit your manuscripts at

http://www.hindawi.com

Journal of
Signal Transduction
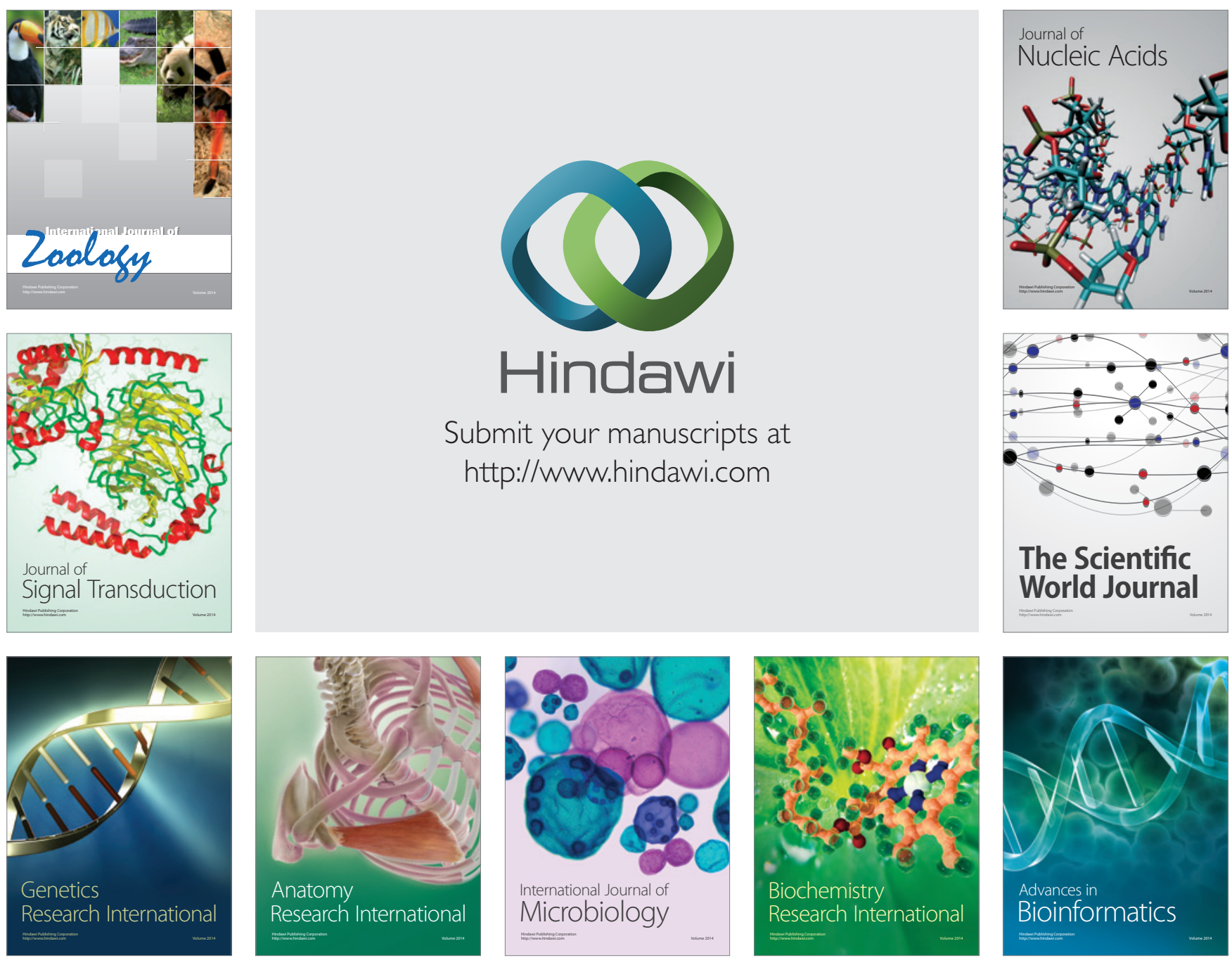

The Scientific World Journal
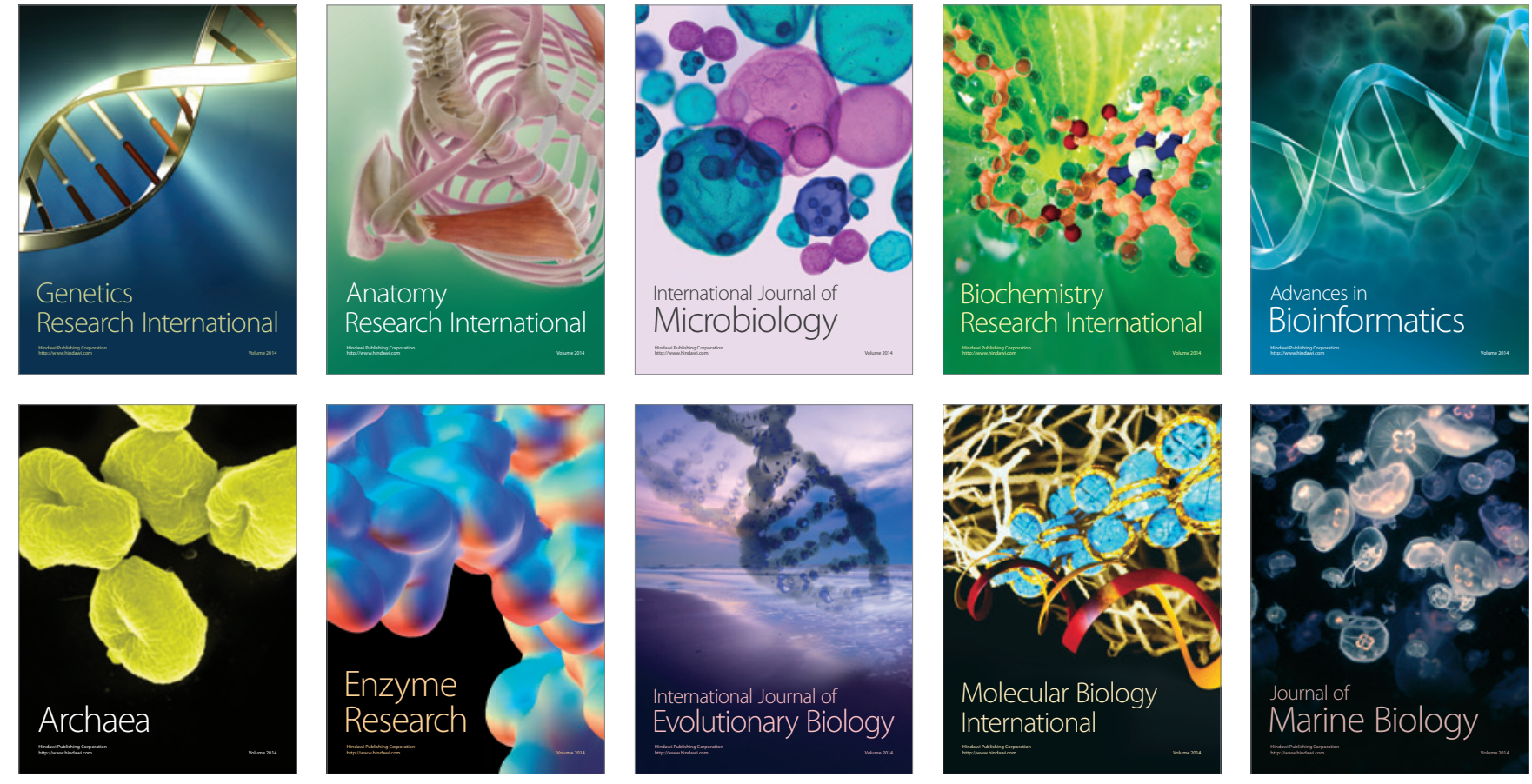